\title{
Top aide to face charges in French HIV blood scandal
}

Paris. France's HIV-contaminated blood scandal returned to the front pages last week with the decision to charge Louis Schweitzer, head of the private office of Laurent Fabius, who was prime minister when the affair occurred in 1985, with 'complicity in poisoning

The decision to press charges against Schweitzer - grand-nephew of the French missionary Albert Schweitzer and now head of the automobile group Renault - was announced on 19 May. Three days later similar charges were brought against Patrick Baudry, former adviser to Georgina Dufoix, who was minister of social affairs in 1985.

Both moves follow the earlier decision by French legal authorities to pursue former ministers and their staff for involvement in the alleged decision to delay the screening of donated blood for HIV in 1985.

But the decision to take legal action based on allegations of 'poisoning' continues to shock many, including some who lodged the initial complaints. More than one third of the latter have decided not to pursue such charges against Michel Garetta, the former head of the National Blood Transfusion Centre, and Jean-Pierre Allain, formerly head of research at the centre, both of whom have already been convicted for 'deception over the quality of a product'.

"It does not shock me at all that the legal authorities are trying to clarify what happened," says Axel Kahn, of the Institute of Molecular Biology at the Cochin Hospital in Paris. "But the charge of 'poisoning' totally lacks credibility."

Many believe that under French law, poisoning must include both direct 'administration' of lethal substances, and evidence of a deliberate attempt on the life of a victim.

From March 1985, the political authorities were warned of the probable contamination of blood products prepared to pooled blood donations. At the same time, the American company Abbott was waiting for authorization to distribute a screening test on the French market, while the French company Pasteur-Diagnostic was said to be putting the finishing touches to its own test.

Schweitzer and Baudry are being held partly responsible for an alleged delay in introducing the screening of blood products. Schweitzer is being blamed for protecting the interests of the company Pasteur Diagnostics, and Baudry, as a representative of his ministry, is being blamed for refusing to accept that the costs of screening should be covered by social security.

It was only on 19 June 1985 that Fabius made screening obligatory. The French test was registered on 21 June, and the Abbott test on 24 July.

Catherine Tastemain

\section{Academy backs science in Endangered Species Act}

Washington. For the second time in less than a month, a report from the US National Academy of Sciences has landed squarely in the middle of a political controversy. Early last month, an academy document on wetlands was published in the middle of a House spat over their definition. This time, the academy has stepped in with a report on endangered species during a Congressional battle over reauthorizing the Endangered Species Act (ESA).

The academy report, released last week after a two-and-a-half-year study, endorses the basic scientific underpinnings of the 22year-old law that protects rare plants and animals in danger of extinction - despite claims by critics in Congress that the law is based on faulty science.

"I can't identify a major scientific flaw" in the act, said Michael Clegg, professor of genetics at the University of California, Riverside, who chaired the study, during a public briefing on the report. The committee did not deny that the act could be improved; but, to the chagrin of property rights advocates in Caught by the act: the bald Congress who would like eagle is no longer endangered. the ESA scaled back (see Nature, 374, 9; 1995), its suggested fixes would probably mean even more protection for wildlife.

In order to put the listing of threatened plants and animals on a more objective footing, the panel recommends the identification of what it calls "evolutionary units," or EU. Each would be defined as "a segment of biological diversity that shares a common evolutionary lineage and contains the potential for a unique evolutionary future."

Such a scheme would be similar to that already used by the National Marine Fisheries Service - one of two US agencies charged with setting guidelines for the protection of endangered species - to distinguish among marine taxa.

But the panel reaffirms the Endangered Species Act's basic premise: that protection of subspecies and populations is scientifically justified. This has been a bone of contention in debates over the spotted owl, one subspecies of which is plentiful in Mexico, and another of which is endangered in the timber forests of the American northwest. Some critics of the ESA have argued that unless the whole species is endangered, it should not be given protection.

The report also asserts that habitat is essential to a species' survival, and thus deserves protection under the act. "The link between species survival and habitat is indisputable," says Clegg. The US Supreme Court is expected to decide this summer whether destroying habitat can be legally considered to be harmful to a species.

The report throws cold water on the idea that captive breeding and the reintroduction of endangered species are viable alternatives to preserving native habitat. The committee accepts that captive breeding may be successful in some cases. But it recommends that it be "avoided when possible", and used only as a last resort to protect a species from extinction.

Although none of this is welcome news for critics of the ESA, the study has so far been spared the angry attacks that greeted - an academy wetlands report released earlier last month (see Nature, 375, 171; 1995). But property rights advocates in Congress have still tried to put their own spin on the new report.

The day after its release, for example, Richard Pombo (Republican, California) told a hearing of the House endangered species task- force, which he chairs, that while it was important to consider the views of scientists, "it is our job to ensure that science is not used as an excuse or a basis for trampling on the constitutional or legal rights of any individual".

But Newt Gingrich (Republican, Georgia), the speaker of the House, who stepped into the hearing for a brief statement, was less combative, suggesting that the two sides of the ESA debate might reach a compromise. Gingrich applauded the academy report's emphasis on preserving biodiversity rather than individual species, and spoke of his own "deep concern for the biological diversity of the planet".

Perhaps it is because they hold most of the cards that conservative Republicans can afford to be gracious. Having already imposed a moratorium on the listing of new species, and proposed deep cuts in the funding of agencies such as the Fish and Wildlife Service that implement the ESA, conservative Republicans also head the House and Senate committees that are responsible for rewriting the act later this year.

Pombo describes the coming debate over reauthorization as "one of the most controversial issues we will take up as a Congress". Gingrich is calling for a revised act that is "economically rational" and "biologically correct", and safeguards private property. But even he admits that balancing such interests will not be easy. Tony Reichhardt 